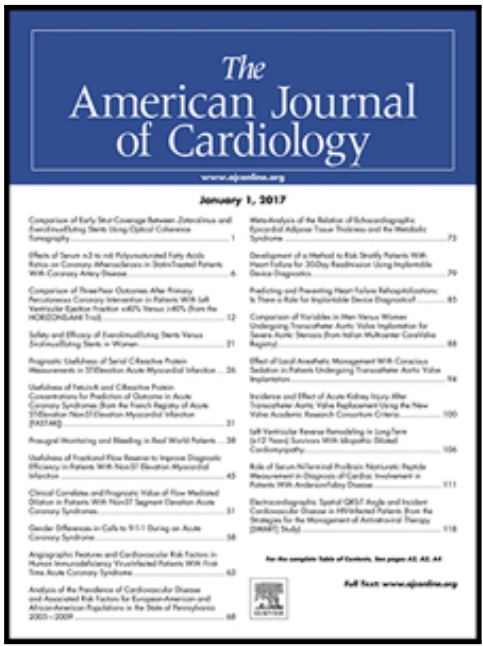

Perioperative Bleeding In Patients With Acute Coronary Syndrome Treated With Fondaparinux Versus Low-Molecular-Weight Heparin Before Coronary Artery Bypass Grafting

Sorosh Khodabandeh MD, Fausto Biancari MD, PhD , Eeva-Maija Kinnunen MD, PhD, Giovanni Mariscalco MD, PhD , Juhani Airaksinen MD, PhD , Riccardo Gherli MD , Giuseppe Gatti MD , Till Demal MD , Francesco Onorati MD, PhD , Giuseppe Faggian MD , Marisa De Feo MD, PhD , Giuseppe Santarpino MD, PhD , Antonino S. Rubino MD, PhD , Daniele Maselli MD , Antonio Salsano MD , Francesco Nicolini MD, PhD, Marco Zanobini MD, PhD, Vito G. Ruggieri MD, PhD, Karl Bounader MD , Andrea Perrotti MD, PhD , Magnus Dalén MD, PhD

PII:

DOI: S0002-9149(18)32109-X

Reference: https://doi.org/10.1016/j.amjcard.2018.11.028 AJC 23640

To appear in: The American Journal of Cardiology

Received date: 28 September 2018

Revised date: 1 November 2018

Please cite this article as: Sorosh Khodabandeh MD, Fausto Biancari MD, PhD , Eeva-Maija Kinnunen MD, PhD , Giovanni Mariscalco MD, PhD , Juhani Airaksinen MD, PhD , Riccardo Gherli MD , Giuseppe Gatti MD , Till Demal MD , Francesco Onorati MD, PhD , Giuseppe Faggian MD , Marisa De Feo MD, PhD , Antonino S. Rubino MD, PhD , Daniele Maselli MD , Giuseppe Santarpino MD, PhD , Antonio Salsano MD , Francesco Nicolini MD, PhD, Marco Zanobini MD, PhD , Vito G. Ruggieri MD, PhD , Karl Bounader MD , Andrea Perrotti MD, PhD , Magnus Dalén MD, PhD, Perioperative Bleeding In Patients With Acute Coronary Syndrome Treated With Fondaparinux Versus Low-Molecular-Weight Heparin Before Coronary Artery Bypass Grafting, The American Journal of Cardiology (2018), doi: https://doi.org/10.1016/j.amjcard.2018.11.028

This is a PDF file of an unedited manuscript that has been accepted for publication. As a service to our customers we are providing this early version of the manuscript. The manuscript will undergo copyediting, typesetting, and review of the resulting proof before it is published in its final form. Please note that during the production process errors may be discovered which could affect the content, and all legal disclaimers that apply to the journal pertain. 


\title{
Perioperative Bleeding In Patients With Acute Coronary Syndrome Treated With Fondaparinux Versus Low-Molecular- Weight Heparin Before Coronary Artery Bypass Grafting
}

\author{
Short title: Fondaparinux versus LMWH before CABG
}

Sorosh Khodabandeh, ${ }^{1,2}$ MD, Fausto Biancari, 3,4,5 MD, PhD, Eeva-Maija Kinnunen, ${ }^{5}$ MD, PhD, Giovanni Mariscalco, ${ }^{6,7} \mathrm{MD}, \mathrm{PhD}$, Juhani Airaksinen, ${ }^{3} \mathrm{MD}, \mathrm{PhD}$, Riccardo Gherli, ${ }^{8} \mathrm{MD}$, Giuseppe Gatti, ${ }^{9} \mathrm{MD}$, Till Demal, ${ }^{10}$ MD, Francesco Onorati, ${ }^{11} \mathrm{MD}, \mathrm{PhD}$, Giuseppe Faggian, MD, ${ }^{11}$ Marisa De Feo, ${ }^{12,13} \mathrm{MD}, \mathrm{PhD}$, Giuseppe Santarpino, ${ }^{14}$ MD, PhD, Antonino S. Rubino, ${ }^{13}$ MD, PhD, Daniele Maselli, ${ }^{15}$ MD, Antonio Salsano, ${ }^{7}$ MD, Francesco Nicolini, ${ }^{16}$ MD, PhD, Marco Zanobini, ${ }^{17}$ MD, PhD, Vito G. Ruggieri, ${ }^{18}$ MD, PhD, Karl Bounader, MD, ${ }^{19}$ Andrea Perrotti, ${ }^{20} \mathrm{MD}, \mathrm{PhD}$, and Magnus Dalén, ${ }^{1,2} \mathrm{MD}, \mathrm{PhD}$.

\footnotetext{
1Department of Molecular Medicine and Surgery, Karolinska Institutet, Stockholm, Sweden; 2Department of Cardiac Surgery, Karolinska University Hospital, Stockholm, Sweden; ${ }^{3}$ Heart Center, Turku University Hospital, University of Turku, Turku, Finland;

${ }^{4}$ Department of Surgery, University of Turku, Turku, Finland;

${ }^{5}$ Department of Surgery, Oulu University Hospital and University of Oulu, Oulu, Finland;

${ }^{6}$ Department of Cardiovascular Sciences, Clinical Sciences Wing, University of Leicester, Glenfield Hospital, Leicester, UK;

${ }^{7}$ Department of Cardiovascular Sciences, Cardiac Surgery Unit, S. Camillo-Forlanini Hospital, Rome, Italy;

${ }^{8}$ Division of Cardiac Surgery, Ospedali Riuniti, Trieste, Italy;

${ }^{9}$ Hamburg University Heart Center, Hamburg, Germany;

${ }^{10}$ Division of Cardiovascular Surgery, Verona University Hospital, Verona, Italy;

${ }^{11}$ Department of Cardiothoracic Sciences, University of Caserta, Caserta, Italy;

${ }^{12}$ Cardiovascular Center, Paracelsus Medical University, Nuremberg, Germany and Città di Lecce Hospital GVM Care \& Research, Lecce, Italy;

13Department of Translational Medical Sciences, University of Campania “Luigi Vanvitelli”, Napoli, Italy;

${ }^{14}$ Centro Clinico-Diagnostico "G.B. Morgagni", Centro Cuore, Pedara, Italy;

15Division of Cardiac Surgery, University of Genoa, Genoa, Italy;

16Division of Cardiac Surgery, University of Parma, Parma, Italy;

${ }^{17}$ Department of Cardiac Surgery, Centro Cardiologico - Fondazione Monzino IRCCS, University of Milan;

${ }^{18}$ Division of Cardiothoracic and Vascular Surgery, Robert Debré University Hospital, Reims, France;

19 Division of Cardiothoracic and Vascular Surgery, Pontchaillou University Hospital, Rennes, France;

${ }^{20}$ Department of Thoracic and Cardio-Vascular Surgery, University Hospital Jean Minjoz, Besançon, France.
}

Word count:

Financial support: None

Conflict of interest: None

Corresponding author: Magnus Dalén, MD, PhD, Department of Cardiac Surgery, Karolinska University Hospital, SE-171 76 Stockholm, Sweden. Tel: +46 8517708 37. Fax: +46 8331931. E-mail: magnus.dalen@sll.se 


\section{Abstract}

The perioperative bleeding risk in patients receiving fondaparinux versus low-molecular weight heparin before coronary artery bypass grafting has not been reported. We evaluated perioperative coronary artery bypass grafting -related bleeding in patients with acute coronary syndrome preoperatively treated with fondaparinux or low-molecular weight heparin. All patients with acute coronary syndrome from the prospective, European multicenter registry on Coronary Artery Bypass Grafting (E-CABG) preoperatively treated with fondaparinux or lowmolecular weight heparin undergoing isolated primary CABG were eligible. The primary outcome measure was severe or massive bleeding defined according to the Universal Definition of Perioperative Bleeding stratified by $\mathrm{P}_{2} \mathrm{Y}_{12}$ inhibitor discontinuation. Secondary outcome measures included three additional definitions of major bleeding used in cardiac surgery trials. Propensity score matching was performed to adjust for differences in pre- and perioperative covariates. 1525 patients were included, of whom 276 (18.1\%) received fondaparinux and 1249 (81.9\%) low-molecular weight heparin preoperatively. In the propensity score-matched cohort (245 pairs), the risk of major bleeding according to the Universal Definition of Perioperative Bleeding severe or massive bleeding (11.8 versus $9.0 \%, \mathrm{p}=0.285)$ and the three other major bleeding definitions was similar between the fondaparinux and low-molecular weight heparin cohorts. In conclusion, preoperative treatment with fondaparinux compared to low-molecular weight heparin was associated with similar incidence of perioperative bleeding in patients with acute coronary syndrome undergoing coronary artery bypass grafting.

Clinical Trial Registration: http://www.clinicaltrials.gov. Unique identifier: NCT02319083; European multicenter registry on Coronary Artery Bypass Grafting (E-CABG) registry.

Key words: Bleeding complications; Coronary artery bypass; Fondaparinux; Low-molecular weight heparin. 


\section{Introduction}

The factor Xa inhibitor fondaparinux has been found to be noninferior to low-molecular-weight heparin (LMWH) in reducing ischemic outcomes in patients with non-ST-segment elevation myocardial infarction (NSTEMI) [1]. Patients treated with fondaparinux had fewer severe inhospital bleeding events which was associated with a reduction of short- and long-term mortality [1]. In patients who underwent percutaneous coronary intervention, fondaparinux patients had a lower incidence of major bleeding complications, including access site-related bleeding [2]. These findings were confirmed in a non-trial setting, where fondaparinux was associated with a lower risk for major bleeding events and death compared/with LMWH [3]. European guidelines therefore recommend fondaparinux as the anticoagulant of choice in patients with NSTEMI regardless of the management strategy, unless the patient is scheduled for immediate coronary angiography [4]. The implementation of these guidelines differs between countries and patients with NSTEMI planned to undergo urgent coronary artery bypass grafting (CABG) might have received either fondaparinux or LMWH preoperatively. The risk for CABGrelated bleeding in this setting has not been studied before and is of interest since severe bleeding has been shown to be associated with increased morbidity and mortality [5]. In a prospective, multicenter registry, we sought to evaluate perioperative CABG-related bleeding in patients with acute coronary syndrome (ACS) preoperatively treated with fondaparinux or LMWH.

\section{Methods}

This is a post-hoc study from the European multicenter registry on Coronary Artery Bypass Grafting (E-CABG), which is a prospective observational, multicenter study including patients undergoing isolated CABG. The detailed study protocol for the E-CABG registry has been published previously [6]. The study was approved by the local regional or 
institutional review board according to national guidelines for approval of registry studies. Patient informed consent was collected in institutions where it was required by the Institutional Review Board.

Data were collected consecutively from 16 cardiac surgery centers in six European countries (Finland, France, Germany, Italy, Sweden, and United Kingdom). All adult patients with acute coronary syndrome who were preoperatively treated with fondaparinux or LMWH and underwent isolated primary CABG in one of the participating centers from January 2015 to May 2017 were eligible. Preoperative dose and type of LMWH were not recorded. Exclusion criteria were (1) patients with discontinuation of fondaparinux or LMWH $>24$ hours prior to surgery and (2) patients treated with both fondaparinux and LMWH within 24 hours prior to surgery.

The primary outcome measure was severe or massive bleeding defined according to the Universal Definition of Perioperative Bleeding (UDPB) in adult cardiac surgery [7]. UDPB severe or massive bleeding is defined as including one or more of the following criteria: delayed sternal closure for bleeding, postoperative blood loss more than $1000 \mathrm{ml}$ within 12 hours, 5 or more red blood cell (RBC) units transfused, 5 or more plasma units transfused, the use of recombinant factor VIIa, or reoperation due to excessive bleeding. In the UDPB classification only RBC transfusions administered after chest closure are counted.

Secondary outcome measures included four additional definitions of major bleeding previously used in cardiac surgery trials. Some of the definitions of major bleeding were slightly modified so that they could be employed in the current study. The three secondary definitions of major bleeding were: (1) Bleeding Academic Research Consortium (BARC) CABGrelated bleeding [8] defined by one or more of the following criteria: postoperative chest tube output more than $1000 \mathrm{ml}$ within 12 hours, transfusion of 5 or more units of RBC, reoperation for bleeding, or death due to bleeding; (2) Blood conservation using Antifibrinolytics Randomized Trial (BART) massive bleeding [9] defined by one or more of the following criteria: postoperative chest tube output more than $1500 \mathrm{ml}$ within 12 hours, transfusion of 11 or more 
units of RBCs, reoperation for bleeding, or death secondary to bleeding; (3) E-CABG severe or massive bleeding [10] defined by one or more of the following criteria: transfusion of 5 or more RBC units during hospital stay and/or reoperation for excessive bleeding. Other secondary outcome measures of this study were reoperation for bleeding, 12-hour postoperative chest tube output, decline in hemoglobin during the operation day, number of RBC units transfused per- and postopoperatively, as well as plasma and platelet transfusion.

Variables are described using frequencies and percentages for categorical variables, and means and standard deviations or medians and interquartile range for continuous variables. In the overall cohort, outcomes were compared by independent samples t-test and $\chi^{2}$ test for binary and categorical variables, and analysis of variance for continuous variables. To reduce selection bias, a propensity score was calculated with fondaparinux/LMWH as the dependent variable. In the propensity score-matched cohort, outcomes were compared by univariate conditional logistic regression for binary and categorical variables and by paired samples t-test for continuous variables. The propensity score-matched cohort was constructed by matching of 1 fondaparinux patient to $1 \mathrm{LMWH}$ patient, with a caliper of 0.2 of the standard deviation of the logit of the propensity score (logit standard deviation 0.098 , caliper width 0.02 ) without replacement and giving priority to exact matching. The following variables were included as covariates: age, gender, preoperative hemoglobin level, preoperative platelet count, estimated glomerular filtration rate, days since discontinuation of $\mathrm{P}_{2} \mathrm{Y}_{12}$ receptor inhibitor, acetylsalicylic acid use within 7 days before surgery, oral anticoagulant paused $<2$ days before surgery, use of/unfractionated heparin, stroke, extracardiac arteriopathy, diabetes, dialysis, chronic lung disease, atrial fibrillation, prior percutaneous coronary intervention, left ventricular ejection fraction $\leq 50 \%$, emergency procedure, critical preoperative state, off-pump surgery, bilateral internal mammary artery grafting, and number of distal coronary artery anastomoses. We calculated standardized differences for variables to investigate post-match balance. A standardized difference $<0.1$ was considered to indicate adequate balance between 
variables of the intervention cohorts. A 2-sided $p$ value of $<0.05$ was considered to indicate statistical significance. Analyses were performed using Stata v.15.1 statistical software (StataCorp LP, College Station, TX, USA) and SPSS v.25.0 (IBM Corporation, New York, USA).

\section{Results}

Of 7352 patients included in the E-CABG prospective, multicenter registry, 5687 patients were not eligible. Of the remaining 1665 patients, 139 were excluded owing to discontinuation of fondaparinux or LMWH $>24$ hours prior to surgery and 1 was excluded owing to treatment with both fondaparinux and LMWH within 24 hours prior to surgery (Figure 1). Thus, 1525 patients with ACS who underwent isolated primary CABGand were treated with fondaparinux or LMWH within 24 hours prior to surgery were included in the present analysis. Of these, 276 (18.1\%) had received fondaparinux and 1249 (81.9\%) LMWH preoperatively.

Patient and procedural characteristics are listed in Table 1. Comorbidities differed between the two groups with preoperative extracardiac arteriopathy, chronic pulmonary disease, percutaneous coronary intervention, atrial fibrillation, and dialysis being more common in the LMWH group. Predicted high risk of severe bleeding estimated with the WILL-BLEED risk score [11] was higher in the LMWH group (53.6 vs. 46.0\%).

In the propensity score-matched cohort (245 pairs), baseline characteristics, including predicted risk of severe bleeding, as well as procedural characteristics were well balanced as shown in Table 1. Fondaparinux dose was $2.5 \mathrm{mg}$ once daily in all patients but one who received $5 \mathrm{mg}$ once daily. Patients who received fondaparinux preoperatively were switched to receive LMWH postoperatively.

In the overall cohort, the LMWH-treated patients had a higher incidence of UDPB severe or massive bleeding, as well as the 3 other definitions of major bleeding (BARC CABG- 
related bleeding, BART massive bleeding, E-CABG severe or massive bleeding), compared with fondaparinux-treated patients (Table 2 and Figure 2).

In the propensity score-matched cohort, the risk of major bleeding according to UDPB severe or massive bleeding and other major bleeding definitions was similar between the fondaparinux and LMWH cohorts (Table 2 and Figure 2). Chest tube output and resternotomy rate for bleeding were similar between the two groups.

In patients with UDPB severe or massive bleeding, in-hospital mortality was higher compared with patients without UDPB sever or massive bleeding (11.1\% vs. 1.9\%, $\mathrm{p}<0.001)$.

\section{Discussion}

In this prospective, multicenter registry, after propensity score matching we found that preoperative treatment with fondaparinux compared to LMWH was associated with similar incidence of perioperative bleeding in ACS patients undergoing CABG.

To study the effects of antithrombotic drugs in patients undergoing cardiac surgery is a topic of interest since severe bleeding has been shown to be associated with increased morbidity and mortality in these patients [5]. In contrast to antiplatelet drugs, the effect of fondaparinux versus LMWH on CABG-related bleeding has not been evaluated. A few previous studies investigated the bleeding-related effects of LMWH and unfractionated heparin [12], but none included patients preoperatively treated with fondaparinux. Although European guidelines recommend fondaparinux as the anticoagulant of choice in patients with NSTEMI regardless of the management strategy [4], the implementation of these guidelines differs between countries and patients with NSTEMI planned to undergo urgent CABG might have received either fondaparinux or LMWH preoperatively. This could be owing to that these guidelines are based on studies conducted in populations of general NSTEMI patients [1], not only NSTEMI patients undergoing CABG. A possible concern for increased CABG-related bleeding 
in patients receiving fondaparinux could therefore prevent physicians of using this medication in patients accepted for urgent CABG. Another reason why the implementation of fondaparinux in patients with NSTEMI has differed between European countries could be that it has been argued that the study on fondaprinux versus enoxaparin in ACS patients used a higher enoxaparin dose than the one used currently [1]. Also, fondaparinux in that study was associated with a higher incidence of catheter-related thrombosis which necessitated unfractionated heparin during angiography and PCI [1].

Although bleeding associated with fondaparinux versus LMWH has not been investigated in patients undergoing CABG previously, it has been studied in patients undergoing percutaneous coronary intervention [2]. In these patients, fondaparinux patients had a lower incidence of major bleeding complications, including access site-related bleeding [2]. These are findings from a different clinical setting but still somewhat contrast to the results of the present study, supporting similar periprocedural bleeding in patients receiving fondaparinux or LMWH.

This study has limitations that need to be considered. By using propensity score matching we adjusted for differences in baseline characteristics between patients who had preoperatively received either fondaparinux or LMWH. Still, residual confounding might be present even after adjustment. Preoperative treatment with fondaparinux or LMWH was known by the treating physicians, which may have influenced their decision to use blood transfusions and hemostatic drugs. This could be why red blood cell and platelet transfusions, as well as use of hemostatic drugs differed between the two groups. Furthermore, the type and dose of LMWH administered were not registered. However, the study was prospectively conducted in a multicenter setting with a large number or pre- peri- and postoperative variables. The use of multiple definitions of major perioperative bleeding may more accurately describe major bleeding as incidence differs significantly depending on the bleeding definition used [8].

Preoperative treatment with fondaparinux compared to LMWH was associated with similar incidence of perioperative bleeding in ACS patients undergoing CABG. These 
findings support that the choice between fondaparinux and LMWH in ACS patients considered to be at high probability to undergo CABG do not need to be influenced by the concern about possible risk for perioperative CABG-related bleeding.

\section{References}

1. Fifth Organization to Assess Strategies in Acute Ischemic Syndromes I, Yusuf S, Mehta SR, Chrolavicius S, Afzal R, Pogue J, Granger CB, Budaj A, Peters RJ, Bassand JP, Wallentín L, Joyner C and Fox KA. Comparison of fondaparinux and enoxaparin in acute coronary syndromes. N Engl J Med 2006;354:1464-1476.

2. Mehta SR, Granger CB, Eikelboom JW, Bassand JP, Wallentin L, Faxon DP, Peters RJ, Budaj A, Afzal R, Chrolavicius S, Fox KA and Yusuf S. Efficacy and safety of fondaparinux versus enoxaparin in patients with acute coronary syndromes undergoing percutaneous coronary intervention: results from the OASIS-5 trial. J Am Coll Cardiol 2007;50:17421751.

3. Szummer K, Oldgren J, Lindhagen L, Carrero JJ, Evans M, Spaak J, Edfors R, Jacobson SH, Andell P, Wallentin L and Jernberg T. Association between the use of fondaparinux vs low-molecular-weight heparin and clinical outcomes in patients with non-ST-segment elevation myocardial infarction. JAMA 2015;313:707-716.

4. Roffi M, Patrono C, Collet JP, Mueller C, Valgimigli M, Andreotti F, Bax JJ, Borger MA, Brotons C, Chew DP, Gencer B, Hasenfuss G, Kjeldsen K, Lancellotti P, Landmesser U, Mehilli J, Mukherjee D, Storey RF, Windecker S and Group ESCSD. 2015 ESC Guidelines for the management of acute coronary syndromes in patients presenting without persistent ST-segment elevation: Task Force for the Management of Acute Coronary Syndromes in Patients Presenting without Persistent ST-Segment Elevation of the European Society of Cardiology (ESC). Eur Heart J 2016;37:267-315. 
5. Ranucci M, Baryshnikova E, Castelvecchio S, Pelissero G, Surgical and Clinical Outcome Research G. Major bleeding, transfusions, and anemia: the deadly triad of cardiac surgery. Ann Thorac Surg 2013;96:478-485.

6. Biancari F, Ruggieri VG, Perrotti A, Svenarud P, Dalén M, Onorati F, Faggian G, Santarpino G, Maselli D, Dominici C, Nardella S, Musumeci F, Gherli R, Mariscalco G, Masala N, Rubino AS, Mignosa C, De Feo M, Della Corte A, Bancone C, Chocron S, Gatti G, Gherli T, Kinnunen EM and Juvonen T. European Multicenter Study on Coronary Artery Bypass Grafting (ECABG registry): Study Protocol for a Prospective Clinical Registry and Proposal of Classification of Postoperative Complications. J Cardiothorac Surg 2015;10:90.

7. Dyke C, Aronson S, Dietrich W, Hofmann A, Karkouti K, Levi M, Murphy GJ, Sellke FW, Shore-Lesserson L, von Heymann C and Ranucci M. Universal definition of perioperative bleeding in adult cardiac surgery. J Thorac Cardiovasc Surg 2014;147:1458-1463 e1451.

8. Mehran R, Rao SV, Bhatt DL, Gibson CM, Caixeta A, Eikelboom J, Kaul S, Wiviott SD, Menon V, Nikolsky E, Serebruany V, Valgimigli M, Vranckx P, Taggart D, Sabik JF, Cutlip DE, Krucoff MW, Ohman EM, Steg PG and White H. Standardized bleeding definitions for cardiovascular clinical trials: a consensus report from the Bleeding Academic Research Consortium. Circulation 2011;123:2736-2747.

9. Fergusson DA, Hebert PC, Mazer CD, Fremes S, MacAdams C, Murkin JM, Teoh K, Duke PC, Arellano R, Blajchman MA, Bussieres JS, Cote D, Karski J, Martineau R, Robblee JA, Rodger M, Wells G, Clinch J, Pretorius R and Investigators B. A comparison of aprotinin and lysine analogues in high-risk cardiac surgery. N Engl J Med 2008;358:2319-2331.

10. Mariscalco G, Gherli R, Ahmed AB, Zanobini M, Maselli D, Dalén M, Piffaretti G, Cappabianca G, Beghi C and Biancari F. Validation of the European Multicenter Study on Coronary Artery Bypass Grafting (E-CABG) Bleeding Severity Definition. Ann Thorac Surg 2016;101:1782-1788.

11. Biancari F, Brascia D, Onorati F, Reichart D, Perrotti A, Ruggieri VG, Santarpino G, Maselli D, Mariscalco G, Gherli R, Rubino AS, De Feo M, Gatti G, Santini F, Dalén M, Saccocci M, 
Kinnunen EM, Airaksinen JK, D'Errigo P, Rosato S and Nicolini F. Prediction of severe bleeding after coronary surgery: the WILL-BLEED Risk Score. Thromb Haemost 2017; 117:445-456.

12. Kincaid EH, Monroe ML, Saliba DL, Kon ND, Byerly WG and Reichert MG. Effects of preoperative enoxaparin versus unfractionated heparin on bleeding indices in patients undergoing coronary artery bypass grafting. Ann Thorac Surg 2003;76:124-128; discussion 128. 


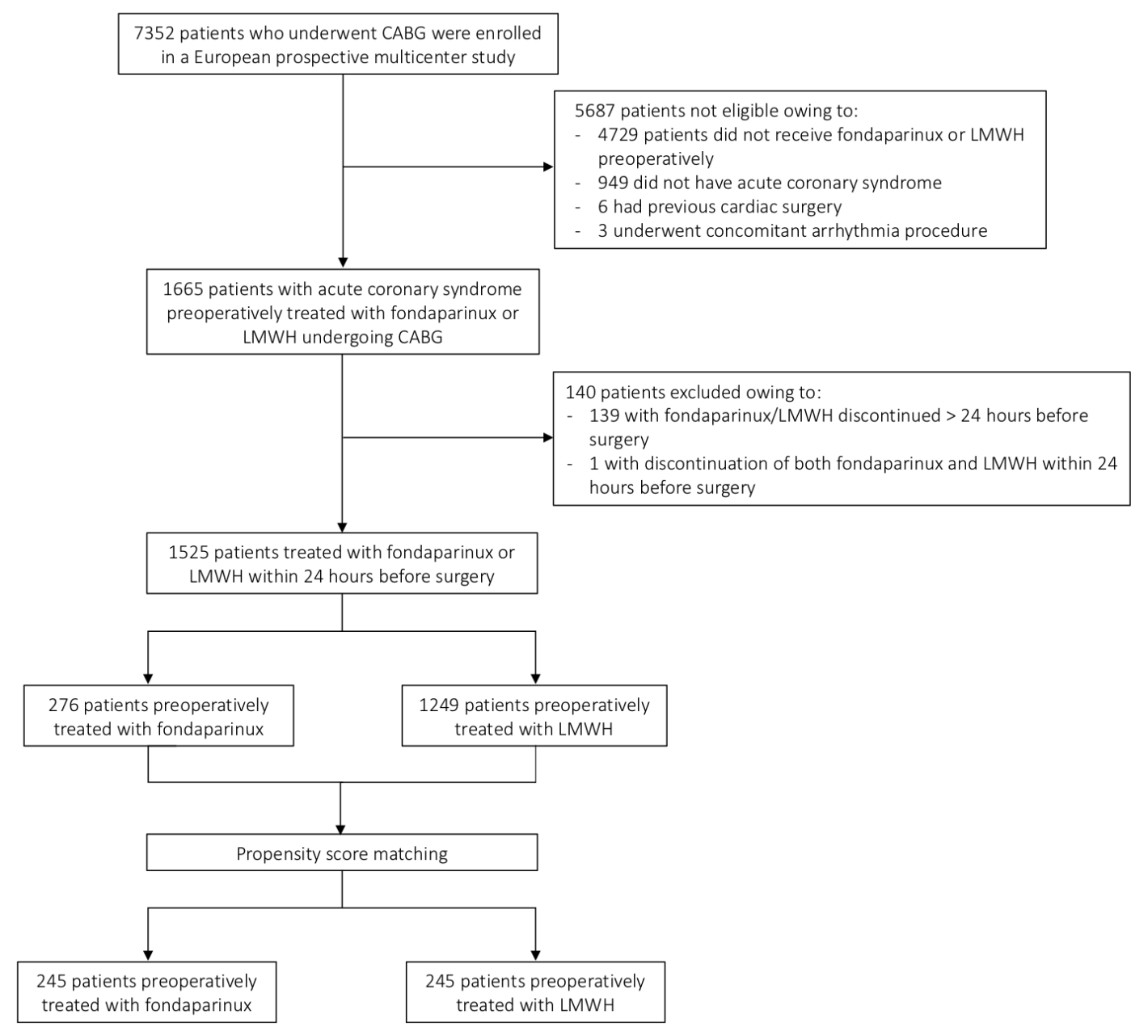

Figure 1

Study flow chart. ACS = acute coronary syndrome, $\mathrm{CABG}=$ coronary artery bypass grafting, $\mathrm{LMWH}=$ low molecular weight heparin. 

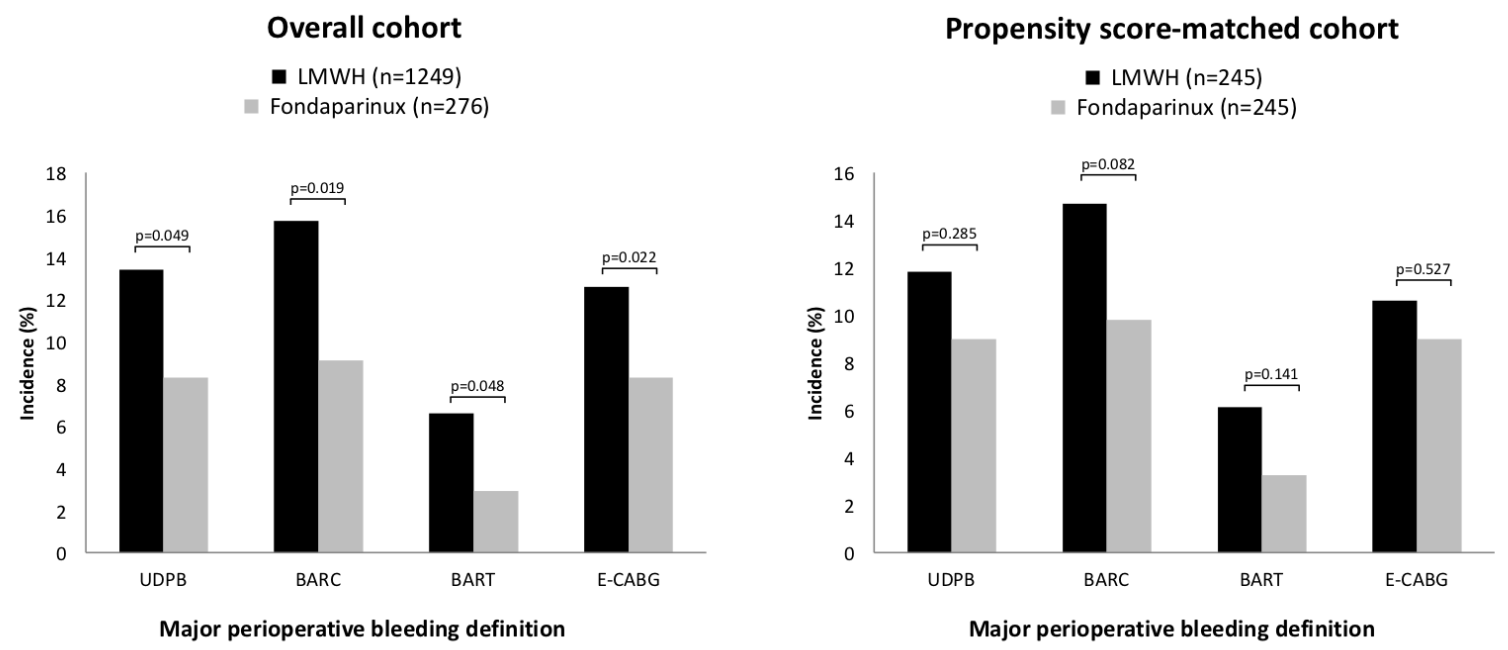

\section{Figure 2}

Incidence of major perioperative bleeding between patients preoperatively treated with fondaparinux versus low-molecular weight heparin according to 4 definitions: UDPB severe or massive bleeding, BARC CABG-related bleeding, BART massive bleeding, and E-CABG severe or massive bleeding. Left panels: Overall cohort. Right panels: Propensity score-matched cohort. BARC CABG = Bleeding Academic Research Consortium, BART $=$ Blood conservation using Antifibrinolytics Randomized Trial, E-CABG = European multicenter study on Coronary Artery Bypass Grafting, UDPB = Universal Definition of Perioperative Bleeding. 
Table 1 Patient and procedural characteristics

\begin{tabular}{|c|c|c|c|c|c|c|}
\hline & $\begin{array}{l}\text { Overall } \\
\text { cohort }\end{array}$ & $\begin{array}{l}\text { Propensit } \\
\text { y score- } \\
\text { matched } \\
\text { cohort }\end{array}$ & & & & \\
\hline Variable & $\begin{array}{l}\text { Fondaparinu } \\
x \mathrm{n}=276\end{array}$ & $\begin{array}{l}\mathrm{LMWH} \\
\mathrm{n}=1249\end{array}$ & $\begin{array}{l}\text { Standardize } \\
\text { d difference }\end{array}$ & $\begin{array}{l}\text { Fondaparinu } \\
x \mathrm{n}=245\end{array}$ & $\begin{array}{l}\mathrm{LMWH} \\
\mathrm{n}=245\end{array}$ & $\begin{array}{l}\text { Standardize } \\
\text { d difference }\end{array}$ \\
\hline $\begin{array}{l}\text { Age (years) } \\
\text { mean } \pm \text { SD }\end{array}$ & $66.1 \pm 9.9$ & $66.9 \pm 9.7$ & -0.0835 & $66.1 \pm 9.8$ & $\begin{array}{l}66.2 \pm \\
10.4 \\
\end{array}$ & -0.0081 \\
\hline Women & 48 (17.4\%) & $\begin{array}{l}249 \\
(19.9 \%)\end{array}$ & -0.0653 & 44 (18.0\%) & $\begin{array}{l}44 \\
(18.0 \% \\
)\end{array}$ & \\
\hline Stroke & $11(4.0 \%)$ & $64(5.1 \%)$ & -0.0546 & $9(3.7 \%)$ & 13 & -0.0787 \\
\hline $\begin{array}{l}\text { Extracardiac } \\
\text { arteriopathy }\end{array}$ & 40 (14.5\%) & $\begin{array}{l}314 \\
(25.1 \%)\end{array}$ & -0.2693 & $40(16.3 \%)$ & $\begin{array}{l}45 \\
(18.4 \%\end{array}$ & -0.0538 \\
\hline $\begin{array}{l}\text { Diabetes } \\
\text { mellitus }\end{array}$ & $83(30.1 \%)$ & $\begin{array}{l}436 \\
(34.9 \%)\end{array}$ & -0.1033 & $72(29.4 \%)$ & $\begin{array}{l}81 \\
(33.1 \%\end{array}$ & -0.0792 \\
\hline Dialysis & 0 & $23(1.8 \%)$ & & 0 & 0 & - \\
\hline $\begin{array}{l}\text { Chronic lung } \\
\text { disease }\end{array}$ & $16(5.8 \%)$ & $\begin{array}{l}176 \\
(14.1 \%)\end{array}$ & -0.2796 & $15(6.1 \%)$ & $\begin{array}{l}14 \\
(5.7 \%)\end{array}$ & 0.0173 \\
\hline Atrial fibrillation & $12(4.3)$ & $129(10.3)$ & -0.2309 & 12 (4.9\%) & $\begin{array}{l}13 \\
(5.3 \%)\end{array}$ & -0.0185 \\
\hline $\begin{array}{l}\text { Prior } \\
\text { percutaneous } \\
\text { coronary } \\
\text { intervention }\end{array}$ & 40 (14.5\%) & & -0.2262 & 40 (16.3\%) & $\begin{array}{l}38 \\
(15.5 \% \\
)\end{array}$ & 0.0223 \\
\hline $\begin{array}{l}\text { Left ventricular } \\
\text { ejection fraction } \\
\leq 50 \%\end{array}$ & $103(37.3 \%)$ & $\begin{array}{l}488 \\
(39.1 \%)\end{array}$ & -0.0367 & 91 (37.1\%) & $\begin{array}{l}101 \\
(41.2 \% \\
)\end{array}$ & -0.0835 \\
\hline $\begin{array}{l}\text { Emergent or } \\
\text { salvage } \\
\text { procedure }\end{array}$ & $21(7.6 \%)$ & $\begin{array}{l}108 \\
(8.6 \%)\end{array}$ & -0.0380 & $19(7.8 \%)$ & $\begin{array}{l}18 \\
(7.3 \%)\end{array}$ & 0.0154 \\
\hline $\begin{array}{l}\text { Critical } \\
\text { preoperative } \\
\text { state }\end{array}$ & $14(5.1 \%)$ & $\begin{array}{l}128 \\
(10.2 \%)\end{array}$ & -0.1954 & $14(5.7 \%)$ & $\begin{array}{l}12 \\
(4.9 \%)\end{array}$ & 0.0364 \\
\hline \multicolumn{7}{|l|}{$\begin{array}{l}\text { Preoperative } \\
\text { laboratory } \\
\text { parameters }\end{array}$} \\
\hline $\begin{array}{l}\text { Hemoglobin } \\
(\mathrm{g} / \mathrm{L}) \text { mean } \pm S D\end{array}$ & $137 \pm 17$ & $133 \pm 18$ & 0.2193 & $137 \pm 17$ & $\begin{array}{l}136 \pm \\
17\end{array}$ & 0.0712 \\
\hline $\begin{array}{l}\text { Platelets } \\
\left(\times 10^{9} / \mathrm{L}\right) \text { mean } \pm \\
\text { SD }\end{array}$ & $235 \pm 70$ & $233 \pm 74$ & 0.0210 & $235 \pm 71$ & $\begin{array}{l}235 \pm \\
86\end{array}$ & 0.0050 \\
\hline
\end{tabular}




\begin{tabular}{|c|c|c|c|c|c|c|}
\hline $\begin{array}{l}\text { Estimated } \\
\text { glomerular } \\
\text { filtration rate } \\
\left(\mathrm{ml} / \mathrm{min} / 1,73 \mathrm{~m}^{2}\right. \\
) \text { mean } \pm \mathrm{SD}\end{array}$ & $84 \pm 26$ & $84 \pm 29$ & 0.0039 & $84 \pm 26$ & $84 \pm 27$ & -0.0050 \\
\hline \multicolumn{7}{|l|}{$\begin{array}{l}\text { Preoperative } \\
\text { antithrombotic } \\
\text { medications }\end{array}$} \\
\hline $\begin{array}{l}\text { Acetylsalicylic } \\
\text { acid }\end{array}$ & 261 (94.6\%) & $\begin{array}{l}1119 \\
(89.6 \%)\end{array}$ & 0.1848 & 231 (94.3\%) & $\begin{array}{l}232 \\
(94.7 \% \\
1\end{array}$ & -0.0179 \\
\hline $\begin{array}{l}\text { Unfractionated } \\
\text { heparin }\end{array}$ & 0 & $6(0.5 \%)$ & -0.0982 & 0 & $\begin{array}{l}1 \\
(0.4 \%)\end{array}$ & -0.0904 \\
\hline Warfarin & $1(0.4 \%)$ & $21(1.7 \%)$ & -0.1314 & $1(0.4 \%)$ & 0 & 0.0904 \\
\hline $\begin{array}{l}\text { Novel oral } \\
\text { anticoagulant }\end{array}$ & 0 & $4(0.3 \%)$ & -0.0801 & 0 & $\frac{1}{(0.4 \%)}$ & -0.0904 \\
\hline $\begin{array}{l}\text { Days since } \\
\text { discontinuation } \\
\text { of ticagrelor, } \\
\text { clopidogrel, or } \\
\text { prasugrel }\end{array}$ & & & 0.0547 & & & 0.0884 \\
\hline $0-3$ & 77 (57.5\%) & $\begin{array}{l}196 \\
(54.7 \%)\end{array}$ & & $69(57.0 \%)$ & $\begin{array}{l}40 \\
(52.6 \% \\
1\end{array}$ & \\
\hline $4-5$ & 57 (42.5\%) & $\begin{array}{l}162 \\
(45.3 \%)\end{array}$ & & 52 (43.0\%) & $\begin{array}{l}36 \\
147.4 \% \\
1\end{array}$ & \\
\hline $\begin{array}{l}\text { WILL-BLEED } \\
\text { bleeding risk } \\
\text { score }\end{array}$ & & & 0.1658 & & & 0.0447 \\
\hline Low risk $(<4)$ & 44 (15. & $\begin{array}{l}197 \\
(15.8 \%)\end{array}$ & & $36(14.7 \%)$ & $\begin{array}{l}36 \\
(14.7 \% \\
)\end{array}$ & \\
\hline $\begin{array}{l}\text { Medium risk (4- } \\
6 \text { 6) }\end{array}$ & $105(38.0 \%)$ & $\begin{array}{l}383 \\
(30.7 \%)\end{array}$ & & $91(37.1 \%)$ & $\begin{array}{l}86 \\
(35.1 \%\end{array}$ & \\
\hline High risk $(>6)$ & $127(46.0 \%)$ & $\begin{array}{l}669 \\
(53.6 \%)\end{array}$ & & $118(48.2 \%)$ & $\begin{array}{l}123 \\
(50.2 \% \\
1 \\
\end{array}$ & \\
\hline $\begin{array}{l}\text { Off-pump } \\
\text { surgery }\end{array}$ & $16(5.8 \%)$ & $\begin{array}{l}285 \\
(22.8 \%)\end{array}$ & -0.5008 & $16(6.5 \%)$ & $\begin{array}{l}10 \\
(4.1 \%)\end{array}$ & 0.1092 \\
\hline $\begin{array}{l}\text { Bilateral } \\
\text { internal } \\
\text { mammary } \\
\text { grafting }\end{array}$ & $123(44.6 \%)$ & $\begin{array}{l}187 \\
(15.0 \%)\end{array}$ & 0.6831 & $101(41.2 \%)$ & $\begin{array}{l}97 \\
(39.6 \% \\
)\end{array}$ & 0.0332 \\
\hline $\begin{array}{l}\text { Number of } \\
\text { distal } \\
\text { anastomoses }\end{array}$ & $3.0 \pm 0.8$ & $2.6 \pm 1.0$ & 0.3894 & $2.9 \pm 0.8$ & $\begin{array}{l}2.8 \pm \\
0.9\end{array}$ & 0.1525 \\
\hline
\end{tabular}

Data are $\mathrm{n}(\%)$ unless otherwise noted. $\mathrm{LMWH}=$ low molecular weight heparin, $\mathrm{SD}=$ standard deviation. 
Table 2 Postoperative outcomes

\begin{tabular}{|c|c|c|c|c|c|c|}
\hline & Overall cohort & $\begin{array}{l}\text { Propensity } \\
\text { score- } \\
\text { matched } \\
\text { cohort }\end{array}$ & & & & \\
\hline Variable & $\begin{array}{l}\text { Fondaparinux } \\
n=276\end{array}$ & $\begin{array}{l}\text { LMWH } \\
n=1249\end{array}$ & $\begin{array}{l}\mathrm{p}- \\
\text { value }\end{array}$ & $\begin{array}{l}\text { Fondaparinux } \\
\mathrm{n}=245\end{array}$ & $\begin{array}{l}\text { LMWH } \\
n=245\end{array}$ & $\begin{array}{l}p- \\
\text { value }\end{array}$ \\
\hline \multicolumn{7}{|l|}{$\begin{array}{l}\text { Definitions of major } \\
\text { bleeding }\end{array}$} \\
\hline $\begin{array}{l}\text { UDPB severe or } \\
\text { massive bleeding }\end{array}$ & $24(8.7 \%)$ & $\begin{array}{l}168 \\
(13.5 \%)\end{array}$ & 0.031 & $22(9.0 \%)$ & $\begin{array}{l}29 \\
(11.8 \%)\end{array}$ & 0.285 \\
\hline $\begin{array}{l}\text { BARC CABG-related } \\
\text { bleeding }\end{array}$ & $26(9.4 \%)$ & $\begin{array}{l}197 \\
(15.8 \%)\end{array}$ & 0.007 & $24(9.8 \%)$ & $\begin{array}{l}36 \\
(14.7 \%)\end{array}$ & 0.082 \\
\hline $\begin{array}{l}\text { BART massive } \\
\text { bleeding }\end{array}$ & $9(3.3 \%)$ & $85(6.8 \%)$ & 0.027 & $8(3.3 \%)$ & $\begin{array}{l}15 \\
(6.1 \%)\end{array}$ & 0.141 \\
\hline $\begin{array}{l}\text { E-CABG severe or } \\
\text { massive bleeding }\end{array}$ & $23(8.3 \%)$ & $\begin{array}{l}157 \\
(12.6 \%)\end{array}$ & 0.048 & $22(9.0 \%)$ & $\begin{array}{l}26 \\
(10.6 \%)\end{array}$ & 0.527 \\
\hline $\begin{array}{l}12 \text { hours chest tube } \\
\text { output }(\mathrm{mL}) \text { mean } \pm \\
\text { SD }\end{array}$ & $470 \pm 230$ & $500 \pm 370$ & 0.16 & $470 \pm 230$ & $\begin{array}{l}510 \pm \\
330\end{array}$ & 0.143 \\
\hline $\begin{array}{l}\text { Resternotomy for } \\
\text { bleeding }\end{array}$ & $8(2.9 \%)$ & $56(4.5 \%)$ & 0.23 & $7(2.9 \%)$ & $\begin{array}{l}8 \\
(3.3 \%)\end{array}$ & 0.796 \\
\hline $\begin{array}{l}\text { Decline in hemoglobin } \\
\text { during the operation } \\
\text { day }(g / L) \text { mean } \pm S D\end{array}$ & $37 \pm 15$ & $35 \pm 2 c$ & 0.31 & $36 \pm 16$ & $39 \pm 21$ & 0.145 \\
\hline \multicolumn{7}{|l|}{ Transfusions } \\
\hline $\begin{array}{l}\text { Units of RBC } \\
\text { transfused per- and } \\
\text { postoperative, mean } \pm \\
\text { SD }\end{array}$ & $1.1 \pm 2.5$ & $1.9 \pm 3.3$ & $<0.001$ & $1.2 \pm 2.5$ & $\begin{array}{l}1.8 \pm \\
2.7\end{array}$ & 0.008 \\
\hline Plasma transfused & $17(6.2 \%)$ & $\begin{array}{l}125 \\
(10.0 \%) \\
\end{array}$ & 0.046 & $16(6.5 \%)$ & $\begin{array}{l}24 \\
(9.8 \%)\end{array}$ & 0.193 \\
\hline Platelets transfused & $40(14.5 \%)$ & $119(9.5 \%)$ & 0.015 & $38(15.5 \%)$ & $\begin{array}{l}19 \\
(7.8 \%)\end{array}$ & 0.006 \\
\hline $\begin{array}{l}\text { Any hemostatic drug } \\
\text { administered }\end{array}$ & $6(2.2 \%)$ & $65(5.2 \%)$ & 0.031 & $6(2.4 \%)$ & $\begin{array}{l}17 \\
(6.9 \%)\end{array}$ & 0.009 \\
\hline Atrial fibrillation & $71(25.7 \%)$ & $\begin{array}{l}885 \\
(30.8 \%)\end{array}$ & 0.094 & 60 (24.5\%) & $\begin{array}{l}60 \\
(24.5 \%)\end{array}$ & 0.833 \\
\hline $\begin{array}{l}\text { Maximum } \\
\text { postoperative } \\
\text { creatinine }(\mu \mathrm{mol} / \mathrm{L}) \\
\text { mean } \pm \mathrm{SD}\end{array}$ & $109 \pm 63$ & $119 \pm 106$ & 0.13 & $108 \pm 65$ & $\begin{array}{l}109 \pm \\
51\end{array}$ & 0.838 \\
\hline Dialysis & $5(1.8 \%)$ & $48(3.8 \%)$ & 0.19 & $4(1.6 \%)$ & $\begin{array}{l}2 \\
(0.8 \%)\end{array}$ & 0.410 \\
\hline Stroke & $2(0.7 \%)$ & $21(1.7 \%)$ & 0.24 & $2(0.8 \%)$ & $\begin{array}{l}4 \\
(1.6 \%)\end{array}$ & 0.306 \\
\hline
\end{tabular}




\begin{tabular}{|l|l|l|l|l|l|l|}
\hline $\begin{array}{l}\text { Intensive care unit } \\
\text { stay (days) mean } \pm \text { SD }\end{array}$ & $2.3 \pm 2.4$ & $3.2 \pm 5.2$ & 0.005 & $2.3 \pm 2.4$ & $\begin{array}{l}3.1 \pm \\
5.8\end{array}$ & 0.052 \\
\hline In-hospital death & $4(1.4 \%)$ & $43(3.4 \%)$ & 0.083 & $4(1.6 \%)$ & $\begin{array}{l}4 \\
(1.6 \%)\end{array}$ & 1.0 \\
\hline
\end{tabular}

Data are $\mathrm{n}(\%)$ unless otherwise noted. $\mathrm{BARC}$ CABG $=$ Bleeding Academic Research Consortium, $\mathrm{BART}$ $=$ Blood conservation using Antifibrinolytics Randomized Trial, E-CABG = European multicenter study on Coronary Artery Bypass Grafting, LMWH = low molecular weight heparin, RBC = red blood cells, SD = standard deviation, UDPB = Universal Definition of Perioperative Bleeding. 